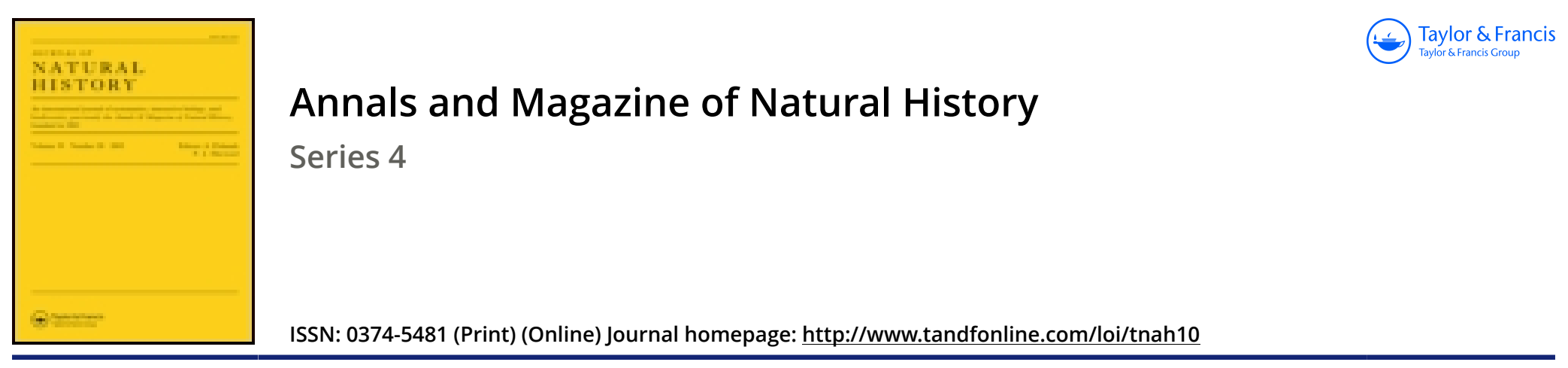

\title{
New observations on the habits of the ants of the south of France
}

\section{T. Moggridge}

To cite this article: T. Moggridge (1874) New observations on the habits of the ants of the south of France, Annals and Magazine of Natural History, 14:79, 89-93, DOI: 10.1080/00222937408680925

To link to this article: http://dx.doi.org/10.1080/00222937408680925

曲 Published online: 13 Oct 2009.

Submit your article to this journal $\pi$

Џ Article views: 5

Q View related articles 5 
growth of fungoid vegetations (not identical with those usually developed after air infection) in plugged bulbs which had been boiled in a can of water.

If it should be hereafter established that Bacteria and fungoid vegetations do, under exceptional circumstances, arise abiogenetically, this would not overturn the panspermic theory, it would merely limit the universality of its application.

\section{MISCELLANEOUS.}

\section{New Observations on the Habits of the Ants of the South of France.} By T. MOGgridge.

A youna Englishman, Mr. Traherne Moggridge, having been compelled for several years, on account of his health, to pass the winter at Mentone, has devoted himself with ardour to the study of the natural history of that portion of the shore of the Mediterranean. He published first, in 1871, an illustrated Flora* of the principal plants which blossom during the winter, with very interesting information respecting their mode of vegetation-and next, in 1873, a little work on the habits of the ants and spiders $\dagger$, which indicates a very remarkable spirit of observation.

We have thought an abstract of Mr. Moggridge's last memoir would be interesting as showing that a subject which was believed to have been long since exhausted, resumed by an intelligent and patient naturalist, may still reveal much that is new and curious. This task has, moreover, been singularly facilitated by the author himself, who has not only most obligingly given us all the information that could be desired upon the places where his observations were made, but communicated several facts which were not known to him at the time of the publication of his work, for which we beg him to accept our best thanks.

[The following is the first of the two sections into which the abstract is divided-that, namely, on the ants.]

In $1869 \mathrm{Mr}$. Bentham, President of the Linnean Society of London, called the attention of naturalists to the paucity of knowledge possessed on the origin of certain plants which appear suddenly in localities where they had been previously unknown, after works necessitating the conveyance of earth. This observation suggested to Mr. Moggridge the idea that the ants which he had seen at Mentone carrying seeds might very probably be an indirect cause of that dissemination. On communicating this opinion to some naturalists, he was much surprised to learn that it was unhesitatingly regarded as a fact by Messrs. Huber, Gould, Kirby, Smith, and recently by

* Contributions to the Flora of Mentone, and to a Winter Flora of the Riviera, including the coast from Marseilles to Genoa. I vol. 8vo. London : L. Reeve \& Co.

† Harresting Ants and Trap-door Spiders-Notes and Observations on their Habits and Dwellings. 1 vol. with plates. 
M. Blanchard, that the ants of Europe make no provision, and that the good La Fontaine was in error when he took, in his Fables, those insects as the type of foresight.

Yet, on the other hand, the most positive assertions are found in several Greek and Latin authors, such as Hesiod, Horace, Virgil, Esop, as well as in the Proverbs of Solomon, that ants aecumulate, during the summer, provisions for the winter; and it is also well established, from the observations of Sykes, Jerdon, Lincecum, Bates, \&c., that the ants of India, Texas, and Brazil hoard up in their ant-hills a considerable quantity of seeds. Confronted by affirmations so contradictory, our author determined, immediately on his return to Mentone in October 1871, to scrutinize with care that which he had previously observed superficially, and thus endeavour to decide the three following questions:-

(1) Are the seeds which are carried into the ant-hills employed as materials of construction? or are they deposited in the interior as provisions?

(2) Do the ants which gather seeds search for grubs as do the other ants?

(3) Do all the ants of the south of Europe, or only some species, convey seeds?

Mr. Moggridge ascertained at once that seeds are transported by three species only :-Atta barbara, of which there are two varietiesone entirely black, the other having a red head; Atta structor, a species very nearly allied to $A$. barbara; and, lastly, Pheidote (Atta) megacephala, a minute yellow ant with a very large head. The facts we will now retrace refer especially to $A$. barbara, which is more readily observed than the other two.

On visiting the ant-hills with which he was already acquainted, he soon found numbers of ants which, assembling in a little meadow in the vicinity, returned loaded with seeds and capsules taken from divers plants (Capsella bursa pastoris, Alsine media, Linn., Calamintha, \&c.). When, for example, a capsule of Bursa pastoris is to be gathered, an ant ascends the cluster, and, neglecting those at the base (which, being dry, let their seeds drop out too readily), attaeks those of the centre, green and well filled; vigorously biting the base of the peduncle, while another ant endeavours to twist it, it is soon detached; the capsule falls on the ground, and is then taken up by other ants.

Can the ants be deceived and carry to their dwelling small bodies having only the appearance of seeds? To enlighten himself on this point Mr. Moggridge strewed the ground with minute grains of porcelain of various colours; a few were carried to the habitation ; but soon the intelligent animals perceived their error, and, returning to their plants, paid no more attention to those objects of no use to them.

The seeds and capsules brought are either deposited for the moment at the entry, or at once carried into the interior of the nest, which, being always excavated in more or less compact sandy soil, requires no foreign substance for its construction, and of which the 
extent may sometimes be very considerable. We may note by the way that, at the end of summer, the ground is covered at a great distance from the entrance with a heap, often considerable, of glumes and empty capsules continually brought from the interior, where the seeds alone are preserved.

The nature of the soil in which ant-hills are found renders very difficult the observation of what takes place within. Mr. Moggridge, desiring much to know the end of the history of these seeds, which he saw enter in so large a quantity, was not discouraged, and at last found an ant-hill which, being parallel to the wall of a terrace, could be with sufficient facility explored throughout. Following the galleries, he ascertained that the seeds (which belonged to more than eighteen families of plants) were carefully accumulated in little cavities or granaries, the size of which varies between that of a watch and that of the palm of the hand. These have a floor carefully made with small grains of mica and quartz cemented together; the upper part has in general the form of a vault. He proved moreover the curious fact that the seeds found in these granaries scarcely ever (hardly one in some thousands) present a commencement of germination, although they are often in conditions of humidity, depth, and temperature very favourable to their development. How can the ants obtain this result? This problem of vegetable physiology has not yet been solved; but Mr. Moggridge has been able to convince himself that it was absolutely necessary, in order that germination should be arrested, that the ants should be able to visit the granaries. If the visits are interrupted, then germination commences immediately. Mr. Moggridge asked himself if formic acid might not be the cause of the suspension of germination; but his recent experiments do not permit him to conclude so.

When, in consequence of certain circumstances, a seed in one of the granaries sprouts, as soon as the radicle has attained a certain length it is cut at its free extremity by the ants; the seed is then taken out of the nest, exposed to the sun, then brought back to the interior and devoured with avidity, as at that time it contains a saccharine substance.

Different colonies of Atta barbara often wage fierce war for the possession of their provisions; and Mr. Moggridge has followed the various phases of a struggle between two swarms, which lasted 46 days (from the 18th January to the 4th of March). It appears that, in fighting, the ants mostly try to seize one another by the antennæ; and when one of them has been thus laid hold of, it immediately loses all energy. Some of the ants appear to be specially charged with the office of plunder; for, on several occasions, Mr. Moggridge observed that the ants which returned loaded with booty delivered it at the entrance of their dwelling to other workers, and set off again immediately.

Although Atta barbara and $A$. structor spend most of their time in gathering seeds, they also pursue small insects, which they either devour at once or carry into their habitations.

Having installed a colony of Atta barbara, with their queen and 
several larvæ, in a large glass bottle full of earth placed in his garden, Mr. Moggridge was able to trace their labours during four months, and to note down the following observations:-

The ants at once commenced digging galleries, working with ardour day and night. As the earth at their disposal was little for the number of workers placed in the bottle, instead of making only one entrance as is usually the case, they made a great number, in order that all the members of the colony might be able to pass in and out without obstruction. Afterwards, when the galleries were more advanced, the entrances, which have often the form of small cones (formed by the accumulation of earthy matters proceeding from the piercing of the galleries), were reduced to three, and at last to one only. At the end of the nineteenth day the ants, quite settled, commenced conveying regularly the seeds which Mr. Moggridge had scattered round the new habitation.

It often happens that the small roots of plants growing at the surface of the ground penetrate into the galleries, thus obstructing the traffic of the ants; but they take care to eut them as soon as they make their appearance, as our author has observed more than once.

Do ants know the value of the treatment of diseases by cold water? One might believe so from the faet, observed by $\mathrm{Mr}$. Moggridge, of an ant immersing another in a little pool of water, on the surface of which a bit of grass floated, which served for a bridge; the ant which had been immersed was afterwards, with difficulty, drawn out of the water, and carried into the sunshine to dry itself.

Mr. Moggridge also convinced himself that the seeds accumulated in the granaries did really serve for the nourishment of the ants; for more than once he had occasion to see the insects detach the particles of a grain of millet, moist and divested of its perisperm, and introduce them into their mouths. When seeds of different sorts were placed at their disposal, some could be eaten at once, others had to be moistened previously. Never in any case were these ants attracted by plant-lice which he placed in their vicinity.

Mr. Moggridge having seen the ants he kept in captivity working at night, he wished to be certain whether this took place habitually. With this view he visited some ant-hills one very dark and hot night, and found a colony actively conveying seeds taken from a neighbouring garden; and if he has not been able to observe the habits of Pheidole megacephala, it is precisely because that species works mostly at night.

The collection of seeds by Atta barbara has been observed at Mentone, Cannes, Marseilles, the Isle of Capri, and Algiers. This species is also found in Germany, Switzerland, and the north of France. What are its habits in the countries of the north? does it there also make provision for the winter? This is not very probable after the precise study bestowed on them by Huber. Nevertheless Mr. Moggridge is very desirous of some naturalist resuming this subject.-Bibliotheque Universelle, Archives des Sciences Phys. et Nat. tome I. pp. 49-56. 